\title{
DISTRIBUTION OF ORGANIC CARBON IN DIFFERENT SOIL FRACTIONS IN ECOSYSTEMS OF CENTRAL AMAZONIA
}

\author{
Jean Dalmo de Oliveira Marques(1)*, Flávio Jesus Luizão(2), Wenceslau Geraldes Teixeira(3), \\ Max Sarrazin(4), Sávio José Filgueira Ferreira(5), Troy Patrick Beldini(5) and Elizalane Moura \\ de Araújo Marques(6)
}

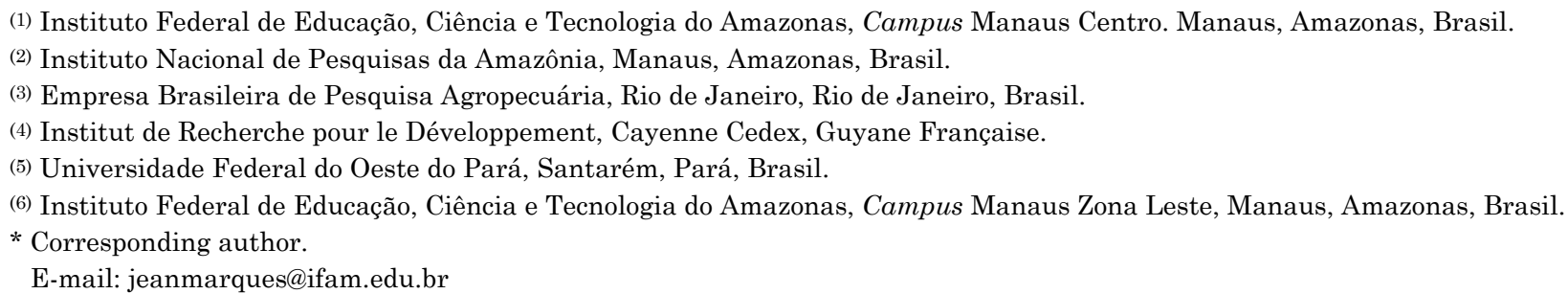

\begin{abstract}
Organic matter plays an important role in many soil properties, and for that reason it is necessary to identify management systems which maintain or increase its concentrations. The aim of the present study was to determine the quality and quantity of organic $\mathrm{C}$ in different compartments of the soil fraction in different Amazonian ecosystems. The soil organic matter (FSOM) was fractionated and soil C stocks were estimated in primary forest (PF), pasture (P), secondary succession (SS) and an agroforestry system (AFS). Samples were collected at the depths 0-5, 5-10, 10-20, 20-40, 40-60, 60-80, 80-100, 100-160, and 160-200 $\mathrm{cm}$. Densimetric and particle size analysis methods were used for FSOM, obtaining the following fractions: FLF (free light fraction), IALF (intra-aggregate light fraction), F-sand (sand fraction), F-clay (clay fraction) and F-silt (silt fraction). The 0-5 cm layer contains $60 \%$ of soil C, which is associated with the FLF. The F-clay was responsible for $70 \%$ of C retained in the 0-200 cm depth. There was a $12.7 \mathrm{~g} \mathrm{~kg}^{-1} \mathrm{C}$ gain in the FLF from PF to SS, and a $4.4 \mathrm{~g} \mathrm{~kg}^{-1} \mathrm{C}$ gain from PF to AFS, showing that SS and AFS areas recover soil organic C, constituting feasible C-recovery alternatives for degraded and intensively farmed soils in Amazonia. The greatest total stocks of carbon in soil fractions were, in decreasing order: $\left(101.3 \mathrm{Mg} \mathrm{ha}^{-1}\right.$ of C - AFS $)>\left(98.4 \mathrm{Mg} \mathrm{ha}^{-1}\right.$ of C - FP $)>\left(92.9 \mathrm{Mg} \mathrm{ha}^{-1}\right.$ of C - SS $)>\left(64.0 \mathrm{Mg} \mathrm{ha}^{-1}\right.$
\end{abstract}




\author{
of $\mathrm{C}-\mathrm{P})$. The forms of land use in the Amazon influence $\mathrm{C}$ distribution in soil fractions, \\ resulting in short- or long-term changes.
}

Keywords: fractionation, soil organic matter, land use, soil physical fractions.

\title{
RESUMO: DISTRIBUIÇÃO DO CARBONO ORGÂNICO NAS FRAÇÕES DO SOLO EM DIFERENTES ECOSSISTEMAS NA AMAZÔNIA CENTRAL
}

\begin{abstract}
A matéria orgânica tem importante papel em diversas propriedades do solo e por isso é necessário identificar sistemas de manejo do solo que favoreçam seu aumento e, ou, mantenham suas concentrações. Este estudo teve como objetivo determinar a qualidade e quantidade de $C$ orgânico em diferentes compartimentos da fração do solo, em diversos ecossistemas amazônicos. Fracionou-se a matéria orgânica do solo e estimou-se os estoques de C em floresta primária (FP), pastagem (P), sucessão secundária (SS) e sistema agroflorestal (SAF). As amostras foram coletadas em profundidades de 0-5, 5-10, 10-20, 20-40, 40-60, 60-80, 80-100, 100-160 e 160-200 cm. Utilizaram-se os métodos densimétrico e granulométrico para o fracionamento da matéria orgânica do solo, obtendo-se: FLL (fração leve livre), FLI (fração leve intraagregada), F-areia (fração areia), F-argila (fração argila) e F-silte (fração silte). Na superfície, $60 \%$ do $C$ do solo estão contidos na camada de $0-5 \mathrm{~cm}$, associados à FLL. A F-argila foi responsável por $70 \%$ do $C$ retido entre 0 e $200 \mathrm{~cm}$ de profundidade. Ocorreu ganho de C de 12,7 $\mathrm{g} \mathrm{kg}^{-1} \mathrm{na} F L L$, comparando-se FP e $S S$; e de 4, $4 \mathrm{~g} \mathrm{~kg}^{-1}$ relacionando FP e SAF, demonstrando que áreas de $S S$ e SAF recuperam o $C$ orgânico do solo, sendo alternativas viáveis de recuperação de solo submetidos à degradação e aos cultivos intensos na Amazônia. Os maiores estoques totais de C nas frações do solo foram: $\left(101,3 \mathrm{Mg} \mathrm{ha}^{-1}\right.$ de $\left.\mathrm{C}-\mathrm{SAF}\right)>$ (98,4 Mg ha-1 de C - FP) > (92,9 $\mathrm{Mg} \mathrm{ha}^{-1}$ de C - SS) > (64,0 $\mathrm{Mg} \mathrm{ha}^{-1}$ de C - P). As formas de uso da terra na Amazônia influenciam a distribuição do $C$ nas frações do solo, ocasionando modificações em curto ou longo prazo.
\end{abstract}

Palavras-chave: fracionamento, matéria orgânica do solo, uso da terra, frações físicas do solo.

\section{INTRODUCTION}

Soil organic matter (SOM) has been an object of investigation in soil and environmental sciences. Physical, biological, and chemical properties of soils are attributed to SOM (Cheng et al., 2007), which is fundamental to the maintenance and sustainability of natural or managed ecosystems. Soil organic matter is considered a product of organic residues, mainly partially decomposed vegetation, in various stages of complexity and structural diversity (Feldpausch et al., 2004; Frouz et al., 2007). It can also be defined as soil $\mathrm{C}$ in all its forms under diverse structural conformations with labile and stable constituents (Passos et al., 2007).

Several factors, including soil texture, original vegetation type, soil management, climate, and especially the quantity and quality of plant residues (Carvalho et al., 2009; Maia et al., 2009), have been identified as controlling the magnitude and speed of change in the content and quality of SOM. Studies for the purpose of better understanding of SOM dynamics in cultivated areas and natural cover are not restricted to evaluation of the levels of total organic $\mathrm{C}$ and thus seek to study the compartments of SOM in order to create soil management strategies for reducing the impact of agriculture on the environment.
Ground plant residues are first fractionated by soil fauna and subsequently decomposed by microorganisms. Most of the $\mathrm{C}$ is oxidized to $\mathrm{CO}_{2}$ and the remainder becomes part of the soil organic matter, interacting with the mineral fraction of the soil (De Bona, 2005). Carbon, as the main constituent of SOM, can accumulate in labile and stable fractions in the soil (Bayer et al., 2006). The study of SOM in its various compartments, as well as its relation to soil management, can generate the theoretical basis for adoption of sustainable land use strategies (Pinheiro et al., 2004). In this regard, the labile fraction is known to be rapidly altered by changes in soil management as compared to the more stable fraction present in silt and clay (De Bona, 2005). The sand fraction is associated with free or labile organic matter, playing an important role in cycling of soil nutrients (Conceição et al., 2005). The silt and clay fractions are associated with most of the soil organic carbon (SOC), not the labile fraction, a material that is more subject to transformation, with an amorphous structure and no recognizable plant material or meso- and microfauna (Roscoe and Machado, 2002). The effect of decomposing soil organic matter is influenced by the clay content of the soil, which increases the uptake of organics and nutrients and provides for enhanced buffering capacity of the soil. Thus, soils with high clay content have higher immobilization of organic C 
(Stürmer et al., 2011) through the action of soil microorganisms (Huang et al., 2008).

Deforestation in the Brazilian Amazon is mainly related to conversion of forests into pastures (Araújo et al., 2011), causing a decrease in soil C, mainly due to rapid mineralization of the labile pool of SOM (Desjardins et al., 2004; Marchão et al., 2009; Rangel and Silva, 2007; Silva Junior et al., 2009). This conversion causes change in the $\mathrm{C}$ content in the soil layers, varying in each fraction in accordance with soil physics (Silva Junior et al., 2009).

However, studies on $\mathrm{C}$ fractionation in Amazon environments must be renewed periodically due to the constant changes they undergo. It is known that changes in natural tropical ecosystems can leverage reductions in soil C inputs (Rangel and Silva, 2007; Awiti et al., 2008; Silva Junior et al., 2009), depending on land use and management, physical and chemical characteristics, and biological soil water, among other aspects. On a regional scale, knowledge of this type of change in land cover and use is critical for assessing the operation of an ecosystem and for landscape planning.

There are no conclusive data regarding the amount of $\mathrm{C}$ released in replacement of native forest by pastures, even in regard to the amount of $\mathrm{C}$ held in the various compartments of the new environment, particularly the soil (Costa et al., 2009). Cardoso et al. (2010) observed that conversion of native areas into pastures promoted increases in carbon stocks. However, in conventional pastures with low levels of fertility and deterioration in soil physical properties, the low production of biomass reduces carbon contents (Silva et al., 2004). An understanding of the organic matter dynamics in soils requires temporal studies, since changes in the SOM and interactions that result from adopted management practices tend to appear gradually (Souza et al., 2009). Recently, agroforestry and secondary succession emerge as alternative cover crops that can imitate the function of keeping forest carbon in different soil compartments, and they are viable alternatives for recovering degraded soils in the Amazon (Marques et al., 2012), requiring further study on their potential storage capacity.

The aim of the present study was to determine the quality and quantity of organic $\mathrm{C}$ in different compartments of the soil fraction in different Amazonian ecosystems.

\section{MATERIAL AND METHODS}

\section{Location of the study areas}

The study was carried out in three areas close to each other (within a radius of $<20 \mathrm{~km}$ ) in Central
Amazon (Table 1). The ecosystems studied were: primary forest $(\mathrm{PF})$, where samples were collected in a catena design on plateau topographic positions located in the Cuieiras Experimental Reserve at km 34 of the ZF-2 side road, about $60 \mathrm{~km}$ north of the city of Manaus, Amazonas, Brazil ( $02^{\circ} 36^{\prime} 32.1^{\prime \prime} \mathrm{S}$ and $\left.60^{\circ} 12^{\prime} 32.4^{\prime \prime} \mathrm{W}\right)$; pasture $(\mathrm{P})$, at the experimental reserve of the Biological Dynamics of Forest Fragments Project (PDBFF), at km 23 of the ZF-3 side road ( $02^{\circ} 25^{\prime} 7^{\prime \prime}$ S and $\left.59^{\circ} 52^{\prime} 51^{\prime \prime} \mathrm{W}\right)$, about $63 \mathrm{~km}$ north of the city of Manaus; an agroforestry system (AFS); and a secondary succession (SS) located at the Western Amazon Agroforestry Research Center (Embrapa CPAA), $54 \mathrm{~km}$ north of Manaus, on the BR-174 highway (2० $32^{\prime} \mathrm{S}$ and $\left.60^{\circ} 02^{\prime} \mathrm{W}\right)$. The soils were classified as Oxisol (Typic Ustox) (Soil Survey Staff, 1998), Latossolo Amarelo according to the Brazilian soil classification system (Embrapa, 2006), or Xanthic Ferralsol (IUSS-WRB, 2006), with a clayey to very clayey texture ( $\mathrm{PF}$ and $\mathrm{P})$, or a very clayey texture (SS and AFS).

\section{Sampling plan}

An experiment was established in August 2007 in forest, pasture, agroforestry system, and secondary succession areas. Soil samples were collected in October 2007, 2008 and 2009 during the dry season always at the same point, one collection each year. In each ecosystem, four plots of $20 \times 40 \mathrm{~m}$ were set up, conducted over two consecutive years, and sampled at the depths of $0-5,5-10,10-20,20-40$, $40-60,60-80,80-100,100-160$, and $160-200 \mathrm{~cm}$, with five replications at each depth, for a total of 180 samples in each ecosystem and 720 samples per year for SOM fractionation analysis and $\mathrm{C}$ stocks in the soil fractions.

\section{Soil analyses}

Soil texture analysis was carried out using the pipette method (Embrapa, 1997). Soil bulk density was determined in undisturbed samples collected with an Uhland-type sampler, using a steel cylinder with a $100 \mathrm{~cm}^{3}$ volume and sampled in each layer with five replicates.

\section{Carbon analyses}

Total $\mathrm{C}$ analyses were determined by gas chromatography carried out with a Fisons Instruments NA 1500 NC Analyzer, using approximately 25-30 mg of material, previously macerated with a mortar and pestle and passed through a $212 \mu \mathrm{m}$ mesh sieve. Carbon concentrations in the soil $\left(\mathrm{C}, \mathrm{kg} \mathrm{m}^{-2}\right)$ were converted to total $\mathrm{C}$ stocks (EC, Mg ha-1). Carbon stocks in each soil layer (C, Mg ha1) from organic matter fractionation were obtained by multiplying the $\mathrm{C}\left(\mathrm{g} \mathrm{kg}^{-1}\right)$ concentration by soil bulk density $\left(\rho, \mathrm{kg} \mathrm{dm}^{-3}\right)$ and the thickness of the soil layer (h, cm) (Equation 1). Carbon stocks by soil profile up to a depth of $200 \mathrm{~cm}$ in each organic 
Table 1. Characteristics of the use and management systems studied

\begin{tabular}{|c|c|}
\hline Use and management system & History \\
\hline Primary forest (PF) & $\begin{array}{l}\text { Consists of dense forest, preserved without alteration, the main additions of carbon occur } \\
\text { through the living and dead plant biomass (crop residues, roots, and exudates). Environment } \\
\text { with the presence of fine litter on the ground, with annual } \mathrm{C} \text { input of around } 3.88 \mathrm{Mg} \mathrm{ha}^{-1} \\
\text { (Luizão, 2007), playing an important role in soil cover and protection, acting as a continuous } \\
\text { and important source of nutrients for the soil, due to its rapid turnover and decomposition. } \\
\text { The coarse litter (thick branches/tree trunks) has slow annual decomposition to carbon, } \\
\text { ranging from } 2 \text { to } 4 \mathrm{Mg} \mathrm{ha}^{-1} \text { (Luizão, 2007). }\end{array}$ \\
\hline Pasture (P) & $\begin{array}{l}\text { Abandoned pasture (with secondary vegetation approximately } 25 \text { years old), cleared in } \\
1970 \text { and subsequently sown mainly to the species Brachiara humidicola, which was used } \\
\text { in a pasture rotational grazing system of semi-confinement, without management of soil } \\
\text { fertility, without use of the slash and burn system, on a softly landscape with Brachiaria } \\
\text { humidicola cover, under study for } 05 \text { years (2005-2010). The carbon intake is through the } \\
\text { action of carbon at the fine root surface, without precise data on carbon input in the soil. }\end{array}$ \\
\hline Agroforestry system (AFS) & $\begin{array}{l}\text { Degraded pasture area abandoned in } 1992 \text { to which an Agroforestry system was deployed, } \\
\text { dominated by Cupuaçu (Theobroma grandiflorum), peach palm (Bactris gassipaes), Açai } \\
\text { palm (Euterpe oleracea), and Andiroba (Carapa guianensis). Carbon contributions are } \\
\text { through litter decomposition, ranging from } 727-2168 \mathrm{~kg} \mathrm{ha}^{-1} \mathrm{yr}^{-1} \mathrm{C} \text { (Tapia-Coral et al., 2005). }\end{array}$ \\
\hline Secondary succession (SS) & $\begin{array}{l}\text { Vegetation arising from natural regeneration of degraded pasture, implemented in } 1992, \\
\text { with } 21 \text { years of growth, dominated by species of the genus Vismia mainly, V. japrurensis, } \\
V . \text { caynensis, and V. guianensis, Laetia procera, Belucia glossularioides and B. dichotoma. } \\
\text { Carbon contributions are through litter decomposition, ranging from } 2457-3966 \mathrm{~kg} \mathrm{ha}^{-1} \mathrm{yr}^{-1} \mathrm{C} \\
\text { (Tapia-Coral et al., 2005). }\end{array}$ \\
\hline
\end{tabular}

fraction $\left(\mathrm{Mg} \mathrm{ha}^{-1}\right)$ were obtained by adding up the $\mathrm{C}$ stocks of the fractions.

$\mathrm{EC}\left(\mathrm{Mg} \mathrm{ha}^{-1}\right)=\mathrm{C}\left(\mathrm{g} \mathrm{kg}^{-1}\right) \times \rho\left(\mathrm{kg} \mathrm{dm}^{-3}\right) \times \mathrm{h}(\mathrm{cm})(1)$

Therefore, calculations of $\mathrm{C}$ stocks were made by mass equivalency of the reference area (Sisti et al., 2004). The process of adjusting the soil mass was conducted from layer to layer considering the difference in soil density. The area used as a reference was a soil under preserved native primary forest.

\section{Fractionation of Soil Organic Matter (FSOM)}

Samples selected for FSOM were analyzed according to the method proposed by Sohi et al. (2001), with the required changes for tropical soils (Roscoe and Machado, 2002; Campos, 2003). Fractionation of soil organic matter was carried out through densimetric (DF) and particle size fractionation (PSF). The FSOM in Central Amazonian clay soils, as studied here, required an adaptation for the method of tropical soils, in accordance with the reduction in clay dispersion (heavy fractions). Samples were added to $20 \mathrm{~mL}$ of sodium pyrophosphate $\left(\mathrm{Na}_{4} \mathrm{P}_{2} \mathrm{O}_{7}\right)$ at a concentration of $50 \mathrm{~g} \mathrm{~L}^{-1}$, corresponding to $1 \mathrm{~g}$ of $\mathrm{Na}_{4} \mathrm{P}_{2} \mathrm{O}_{7}$ and $300 \mathrm{~mL}$ of distilled water, and stirred for $16 \mathrm{~h}$ at $250 \mathrm{rpm}$ in a horizontal shaker. In DF, $5 \mathrm{~g}$ of air-dried soil were weighed in $50 \mathrm{~mL}$ centrifuge flasks, with three replications for each sample, adding $35 \mathrm{~mL}$ de sodium iodide $\left(\mathrm{NaI}, \mathrm{d}=1.80 \mathrm{~kg} \mathrm{dm}^{-3}\right)$ to each one. The flasks were hand shaken for $30 \mathrm{~s}$ so that the less dense organic fractions remained on the surface of the solution and consequently promoted dispersion of unstable aggregates. Subsequently, the samples (soil + NaI) were centrifuged for $30 \mathrm{~min}$ to allow settling of the mineral particles at the bottom of the flask, leaving them at rest for $24 \mathrm{~h}$ for better settling. The organic fraction remaining in the solution (free light fraction) was sucked up together with the NaI solution, and immediately separated by vacuum filtration (Sterifil aseptic system, $47 \mathrm{~mm}$ - Millipore) with previously weighed fiberglass filters $(47 \mathrm{~mm}$ in diameter; $2 \mu \mathrm{m}$ - Whatman GF/A type, lot 1820047). The filtered $\mathrm{NaI}$ solution was returned to the flask containing the remaining soil, and the collected samples were washed with distilled water in order to eliminate excess $\mathrm{NaI}$ present in the fraction and in the filter. The organic fraction and the filter were later weighed and macerated in a porcelain crucible (50 $\mathrm{mm}$ in diameter) until reaching the particle size of talc, passing through a $212 \mu \mathrm{m}$ mesh sieve. After removal of the free light fraction (FLF), the intra-aggregate light fraction (IALF) or occluded fraction was extracted. Ultrasound vibration was applied for 3 min using a Sonifier model 250/450 cell disruptor, with $1.0 \mathrm{~s}$ pulsation intervals and an energy of 206 to $400 \mathrm{~J} \mathrm{~mL}^{-1}$ in the NaI solution. According to Roscoe and Buurman (2000), energy levels from 260 to $275 \mathrm{~J} \mathrm{~mL}^{-1}$ are sufficient to provide dispersion of the soil samples. After sonification, centrifugation was carried out and the samples were left to rest for $36 \mathrm{~h}$, and the IALF collected in the filters was dried, weighed, and ground in the same way as for the FLF. Three laboratory replicates were obtained from each fraction and were mixed to form a single composite sample for determination of total carbon by the dry combustion method (Sohi et al., 2001).

After the light fractionation, sequential extraction was carried out, initiating PSF, where heavy fractions 
represented by the sum of sand, silt, and clay were separated by particle size according to the method proposed by Galvinelli et al. (1995). In PSF, the organic matter from the sand fraction $(\mathrm{F}$-sand) $(>53$ $\mu \mathrm{m})$ was obtained by wet sieving, and those from the silt fraction (F-silt) $(2-53 \mu \mathrm{m})$ and the clay fraction (F-clay) $(0-2 \mu \mathrm{m})$ were determined by collecting aliquots of the particle size fractions of $(0-2 \mu \mathrm{m})$ and $(2-53 \mu \mathrm{m})$, which were separated by sedimentation. Each fraction was later placed in a desiccator, weighed, stored in previously labeled flasks, and kept in a heater at a temperature of $60{ }^{\circ} \mathrm{C}$ to avoid moisture absorption, ground to obtain powder, and dry analyzed using a CHN Perkin Elmer autoanalyzer.

\section{Data analysis}

The data on soil physical properties and $\mathrm{C}$ stocks in each fraction of the ecosystems studied (PF, P, SS, and AFS) are presented as the mean values for each layer and by the sum of the layers followed by standard deviation.

\section{RESULTS}

\section{Soil physical properties and soil organic carbon (SOC)}

In all areas, soil bulk density increased with depth, ranging from 1.040 to $1.240 \mathrm{~kg} \mathrm{dm}^{-3}$ (PF), 1.000 to $1.230 \mathrm{~kg} \mathrm{dm}^{-3}(\mathrm{P}), 1.060$ to $1.310 \mathrm{~kg} \mathrm{dm}^{-3}$ (SS), and 1.150 to $1.320 \mathrm{~kg} \mathrm{dm}^{-3}$ (AFS). The clay contents of the environments ranged from 686 to $868 \mathrm{~g} \mathrm{~kg}^{-1}$ (PF), 784 to $921 \mathrm{~g} \mathrm{~kg}^{-1}(\mathrm{P}), 761$ to $899 \mathrm{~g} \mathrm{~kg}^{-1}$ (SS), and 725 to $910 \mathrm{~g} \mathrm{~kg}^{-1}$ (AFS), increasing with depth (Table 2). The SOC concentrations ranged from 2.0 to $43.3 \mathrm{~g} \mathrm{~kg}^{-1}(\mathrm{PF}), 3.2$ to $41.6 \mathrm{~g} \mathrm{~kg}^{-1}(\mathrm{P})$, 2.6 to $55.7 \mathrm{~g} \mathrm{~kg}^{-1}$ (SS), and 2.5 to $52.6 \mathrm{~g} \mathrm{~kg}^{-1}$ (AFS), decreasing with depth (Table 2).

\section{Carbon contents in the soil physical fractions in different environments}

The FLF, the F-clay, and the F-silt are the main fractions responsible for the retention and availability of SOC in the ecosystems (Table 2). About $60 \%$ of the soil $\mathrm{C}$ is stored in the $0-5 \mathrm{~cm}$ layer, associated with the FLF, with $38.9 \mathrm{~g} \mathrm{~kg}^{-1}$ (SS), $26.2 \mathrm{~g} \mathrm{~kg}^{-1}$ (PF), $30.6 \mathrm{~g} \mathrm{~kg}^{-1}$ (AFS), and $15.9 \mathrm{~g} \mathrm{~kg}^{-1}$ $(\mathrm{P})$, reducing with depth (Table 2 ).

Considering the heavy fractions, the F-clay was responsible for $70 \%$ of the $\mathrm{C}$ retained at the 1.0-2.0 m depth, ranging from 1.8 to $11.6 \mathrm{~g} \mathrm{~kg}^{-1}(\mathrm{PF})$, 2.7 to $13.3 \mathrm{~g} \mathrm{~kg}^{-1}(\mathrm{P}), 2.4$ to $13.5 \mathrm{~g} \mathrm{~kg}^{-1}$ (SS), and 2.2 to $11.8 \mathrm{~g} \mathrm{~kg}^{-1}$ (AFS), increasing with depth. Apparently, in clay soils, organic compounds are physically protected from decomposition due to being located in small pores (Pillon, 2000). The F-silt retains soil $\mathrm{C}$ from 0.1 to $4.5 \mathrm{~g} \mathrm{~kg}^{-1}(\mathrm{PF}), 0.3$ to $5.4 \mathrm{~g} \mathrm{~kg}^{-1}(\mathrm{P})$,
0.1 to $3.5 \mathrm{~g} \mathrm{~kg}^{-1}$ (SS), and 0.2 to $4.8 \mathrm{~g} \mathrm{~kg}^{-1}$ (AFS), whereas the F-sand has the lowest percentage of retention of SOC, ranging from 0.1 to $2.8 \mathrm{~g} \mathrm{~kg}^{-1}(\mathrm{PF})$, 0.1 to $5.7 \mathrm{~g} \mathrm{~kg}^{-1}(\mathrm{P}), 0.1$ to $3.3 \mathrm{~g} \mathrm{~kg}^{-1}$ (SS), and 0.1 to $2.7 \mathrm{~g} \mathrm{~kg}^{-1}$ (AFS), corroborating studies performed on tropical and subtropical soils (Silva et al., 2004).

The changes observed in the mass contents of the FLF and the IALF result from alterations in the quantity and in the quality of the plant residues which are incorporated into the soil, from surface and subsurface input of these residues, and mainly from the different management practices adopted (Soares, 2007). Mutuo et al. (2005) report that C losses on the surface soil, to a $5 \mathrm{~cm}$ depth, can reach $47 \%$ in conventional tillage and from 23 to $29 \%$ in areas with crop rotation. Observing the $\mathrm{C}$ content in the $0-5 \mathrm{~cm}$ surface layer, the SS and AFS ecosystems gain $\mathrm{C}$ at around 12.7 and $4.4 \mathrm{~g} \mathrm{~kg}^{-1}$, respectively, when compared to $\mathrm{PF}$, demonstrating that SS and AFS areas recover SOC. However, in the same layer, in comparing $\mathrm{PF}$ to $\mathrm{P}$, there is a reduction of $10.3 \mathrm{~g} \mathrm{~kg}^{-1}$.

\section{Total carbon stocks in the fractions and layers up to a 2-m depth in PF, P, SS, and AFS}

The $\mathrm{C}$ stocks were higher in the F-clay, the FLF, and the F-silt (Figure 1) throughout the profile, in all environments. The highest FLF carbon stocks in the $0-5 \mathrm{~cm}$ layer occurred in the following decreasing order: AFS (20.9 Mg ha-1) (Figure 1d), SS (18.0 Mg ha-1) (Figure 1c), PF (16.7 Mg ha-1) (Figure 1a), and $\mathrm{P}\left(5.6 \mathrm{Mg} \mathrm{ha}^{-1}\right)$ (Figure 1b). The $\mathrm{C}$ stocks contained in the FLF (0-200 $\mathrm{cm}$ layer) fraction in AFS (26.4 $\left.\mathrm{Mg} \mathrm{ha}^{-1}\right)$, SS (23.2 $\left.\mathrm{Mg} \mathrm{ha}^{-1}\right)$, and $\mathrm{PF}\left(23.1 \mathrm{Mg} \mathrm{ha}^{-1}\right)$ did not show significant differences among themselves, but when compared to pasture (7.9 Mg ha-1) they differed significantly (Table 3 ). The pasture area showed low C stocks in the FLF, the IALF, and F-sand fractions, while the forest showed a higher $\mathrm{C}$ stock in the F-clay (53.4 Mg ha-1) when compared to other ecosystems (Table 3). The $\mathrm{C}$ potentials stocked up to a $2 \mathrm{~m}$ depth in the ecosystems are, in decreasing order: $101.3 \mathrm{Mg}$ ha-1 (AFS), 98.4 Mg ha-1 (PF), 92.9 $\mathrm{Mg} \mathrm{ha}^{-1}$ (SS), and 64.0 Mg ha-1 (P) (Table 3), demonstrating that these Amazonian tropical ecosystems have great potential for sequestering $\mathrm{C}$ at depths.

\section{DISCUSSION}

\section{Soil physics and carbon stocks}

Land use directly influences labile $\mathrm{C}$ and soil physics directly controls $\mathrm{C}$ dynamics in the $\mathrm{F}$-silt, the F-clay, and the F-sand. Along the soil profiles, the AFS and SS areas show C stocks near the PF area, and thus prove to be adequate forms of $\mathrm{C}$ 
Table 2. Soil physical characteristics, soil organic carbon (SOC), and carbon contained in the soil fractions at different depths in primary forest, pasture, secondary succession, and agroforestry system

\begin{tabular}{|c|c|c|c|c|c|c|c|c|}
\hline Depth & Clay & $\rho$ & SOC & FLF & IALF & F-clay & F-silt & F-sand \\
\hline \multirow[t]{2}{*}{$\mathrm{cm}$} & $\mathrm{g} \mathrm{kg}^{-1}$ & $\mathrm{~kg} \mathrm{dm}{ }^{-3}$ & $\mathrm{~g} \mathrm{~kg}^{-1}$ & & & $\mathrm{~g} \mathrm{~kg}^{-1} \mathrm{C}$ & & \\
\hline & \multicolumn{8}{|c|}{ Primary forest } \\
\hline $0-5$ & $686 \pm 0.4$ & $1.040 \pm 0,1$ & $43.3 \pm 0.8$ & $26.2 \pm 14$ & $1.0 \pm 1.0$ & $11.6 \pm 1.4$ & $1.7 \pm 2.6$ & $2.8 \pm 2.1$ \\
\hline $5-10$ & $703 \pm 0.9$ & $1.070 \pm 0,1$ & $35.9 \pm 0.0$ & $11.8 \pm 4.0$ & $0.7 \pm 0.3$ & $16.8 \pm 9.3$ & $4.5 \pm 1.9$ & $2.1 \pm 0.7$ \\
\hline $10-20$ & $794 \pm 1.2$ & $1.110 \pm 0,2$ & $16.5 \pm 0.2$ & $4.7 \pm 1.2$ & $0.6 \pm 0.3$ & $7.6 \pm 0.8$ & $3.2 \pm 0.9$ & $0.4 \pm 0.1$ \\
\hline $20-40$ & $828 \pm 0.2$ & $1.180 \pm 0,1$ & $9.6 \pm 0.0$ & $1.6 \pm 0.5$ & $0.4 \pm 0.2$ & $6.2 \pm 3.0$ & $1.2 \pm 0.4$ & $0.2 \pm 0.0$ \\
\hline $40-60$ & $811 \pm 0.1$ & $1.180 \pm 0,1$ & $6.4 \pm 0.0$ & $0.5 \pm 0.1$ & - & $5.0 \pm 1.2$ & $0.8 \pm 0.4$ & $0.1 \pm 0.0$ \\
\hline $60-80$ & $802 \pm 0.0$ & $1.220 \pm 0,2$ & $4.7 \pm 0.0$ & $0.3 \pm 0.1$ & - & $4.0 \pm 1.6$ & $0.3 \pm 0.1$ & $0.1 \pm 0.0$ \\
\hline $80-100$ & $859 \pm 0.7$ & $1.260 \pm 0,3$ & $4.1 \pm 0.0$ & $0.1 \pm 0.1$ & - & $3.7 \pm 1.2$ & $0.2 \pm 0.1$ & $0.1 \pm 0.0$ \\
\hline $100-160$ & $863 \pm 0.3$ & $1.230 \pm 0,1$ & $2.9 \pm 0.0$ & $0.2 \pm 0.2$ & - & $2.1 \pm 0.5$ & $0.4 \pm 0.2$ & $0.2 \pm 0.2$ \\
\hline \multirow[t]{2}{*}{$160-200+$} & $868 \pm 0.5$ & $1.240 \pm 0,1$ & $2.0 \pm 0.0$ & $0.1 \pm 0.1$ & - & $1.8 \pm 0.7$ & $0.1 \pm 0.0$ & - \\
\hline & \multicolumn{8}{|c|}{ Pasture } \\
\hline $0-5$ & $784 \pm 0.4$ & $1.100 \pm 0,0$ & $41.6 \pm 0.4$ & $15.9 \pm 3.5$ & $1.3 \pm 1.1$ & $13.3 \pm 2.0$ & $5.4 \pm 1.9$ & $5.7 \pm 1.3$ \\
\hline $5-10$ & $815 \pm 0.8$ & $1.000 \pm 0,0$ & $24.4 \pm 0.5$ & $5.9 \pm 2.9$ & $1.1 \pm 0.9$ & $10.8 \pm 2.8$ & $4.3 \pm 2.1$ & $2.3 \pm 0.9$ \\
\hline $10-20$ & $895 \pm 1.6$ & $1.180 \pm 0,0$ & $16.0 \pm 0.1$ & $2.5 \pm 0.3$ & $0.5 \pm 0.5$ & $9.6 \pm 0.8$ & $2.7 \pm 0.4$ & $0.7 \pm 0.1$ \\
\hline $20-40$ & $906 \pm 0.6$ & $1.150 \pm 0,0$ & $9.6 \pm 0.0$ & $1.1 \pm 0.2$ & $0.2 \pm 0.1$ & $6.5 \pm 0.6$ & $1.6 \pm 0.4$ & $0.2 \pm 0.0$ \\
\hline $40-60$ & $913 \pm 0.2$ & $1.120 \pm 0,0$ & $6.1 \pm 0.0$ & $0.4 \pm 0.1$ & - & $5.1 \pm 0.3$ & $0.5 \pm 0.3$ & $0.1 \pm 0.0$ \\
\hline $60-80$ & $913 \pm 0.1$ & $1.230 \pm 0,1$ & $4.8 \pm 0.1$ & $0.3 \pm 0.1$ & - & $4.1 \pm 0.2$ & $0.4 \pm 0.1$ & - \\
\hline $80-100$ & $916 \pm 0.1$ & $1.180 \pm 0,0$ & $4.1 \pm 0.0$ & $0.2 \pm 0.1$ & - & $3.6 \pm 0.3$ & $0.3 \pm 0.1$ & - \\
\hline $100-160$ & $917 \pm 0.1$ & $1.200 \pm 0,0$ & $3.7 \pm 0.0$ & $0.2 \pm 0.1$ & - & $3.1 \pm 0.3$ & $0.4 \pm 0.1$ & - \\
\hline \multirow[t]{2}{*}{$160-200+$} & $921 \pm 0.2$ & $1.210 \pm 0,0$ & $3.2 \pm 0.0$ & $0.1 \pm 0.1$ & - & $2.7 \pm 0.6$ & $0.4 \pm 0.1$ & - \\
\hline & \multicolumn{8}{|c|}{ Secundary succession } \\
\hline $0-5$ & $761 \pm 2.2$ & $1.060 \pm 0,0$ & $55.7 \pm 0.7$ & $38.9 \pm 12.6$ & $2.5 \pm 1.4$ & $8.2 \pm 4.5$ & $2.8 \pm 0.8$ & $3.3 \pm 2.9$ \\
\hline $5-10$ & $789 \pm 3.3$ & $1.130 \pm 0,0$ & $25.3 \pm 1.0$ & $6.5 \pm 2.7$ & $0.9 \pm 0.4$ & $13.5 \pm 2.2$ & $3.5 \pm 1.3$ & $0.9 \pm 0.6$ \\
\hline $10-20$ & $826 \pm 3.0$ & $1.160 \pm 0,0$ & $16.9 \pm 0.1$ & $3.0 \pm 0.6$ & $0.6 \pm 0.3$ & $10.3 \pm 3.0$ & $2.5 \pm 1.5$ & $0.5 \pm 0.2$ \\
\hline $20-40$ & $854 \pm 3.6$ & $1.160 \pm 0,0$ & $10.3 \pm 0.3$ & $1.4 \pm 1.2$ & $0.1 \pm 0.0$ & $6.2 \pm 1.0$ & $2.3 \pm 1.6$ & $0.3 \pm 0.1$ \\
\hline $40-60$ & $862 \pm 3.6$ & $1.180 \pm 0,0$ & $8.3 \pm 0.4$ & $1.0 \pm 0.9$ & $0.2 \pm 0.3$ & $5.7 \pm 1.7$ & $1.3 \pm 0.8$ & $0.1 \pm 0.1$ \\
\hline $60-80$ & $882 \pm 1.2$ & $1.230 \pm 0,0$ & $5.4 \pm 0.1$ & $0.4 \pm 0.2$ & - & $4.4 \pm 0.7$ & $0.6 \pm 0.5$ & - \\
\hline $80-100$ & $885 \pm 0.7$ & $1.240 \pm 0,0$ & $4.3 \pm 0.0$ & $0.3 \pm 0.1$ & - & $3.6 \pm 0.5$ & $0.4 \pm 0.1$ & - \\
\hline $100-160$ & $893 \pm 0.9$ & $1.280 \pm 0,0$ & $3.3 \pm 0.0$ & $0.2 \pm 0.1$ & - & $2.9 \pm 0.2$ & $0.2 \pm 0.1$ & - \\
\hline \multirow[t]{2}{*}{$160-200+$} & $899 \pm 0.9$ & $1.310 \pm 0,0$ & $2.6 \pm 0.0$ & $0.1 \pm 0.0$ & - & $2.4 \pm 0.0$ & $0.1 \pm 0.2$ & - \\
\hline & \multicolumn{8}{|c|}{ Agroforest system } \\
\hline $0-5$ & $725 \pm 7.5$ & $1.150 \pm 0,0$ & $52.6 \pm 1.2$ & $30.6 \pm 12.6$ & $3.0 \pm 2.0$ & $11.8 \pm 4.2$ & $4.5 \pm 3.1$ & $2.7 \pm 1.7$ \\
\hline $5-10$ & $757 \pm 2.1$ & $1.210 \pm 0,0$ & $24.5 \pm 0.3$ & $6.1 \pm 2.5$ & $1.1 \pm 0.7$ & $11.3 \pm 1.8$ & $4.8 \pm 1.8$ & $1.2 \pm 0.9$ \\
\hline $10-20$ & $865 \pm 2.8$ & $1.260 \pm 0,0$ & $15.8 \pm 0.1$ & $2.8 \pm 1.0$ & $0.4 \pm 0.2$ & $9.9 \pm 1.6$ & $2.3 \pm 0.7$ & $0.4 \pm 0.2$ \\
\hline $20-40$ & $877 \pm 0.5$ & $1.270 \pm 0,0$ & $11.4 \pm 0.0$ & $1.1 \pm 0.4$ & $0.3 \pm 0.2$ & $7.9 \pm 1.2$ & $1.4 \pm 0.4$ & $0.7 \pm 0.9$ \\
\hline $40-60$ & $872 \pm 0.6$ & $1.280 \pm 0,0$ & $7.1 \pm 0.0$ & $0.6 \pm 0.2$ & - & $5.5 \pm 0.4$ & $0.9 \pm 0.3$ & $0.1 \pm 0.0$ \\
\hline $60-80$ & $881 \pm 0.8$ & $1.310 \pm 0,0$ & $5.6 \pm 0.0$ & $0.3 \pm 0.2$ & - & $4.6 \pm 0.3$ & $0.7 \pm 0.3$ & - \\
\hline $80-100$ & $888 \pm 0.9$ & $1.300 \pm 0,0$ & $4.9 \pm 0.0$ & $0.3 \pm 0.2$ & - & $4.0 \pm 0.3$ & $0.6 \pm 0.1$ & - \\
\hline $100-160$ & $902 \pm 0.9$ & $1.290 \pm 0,0$ & $2.9 \pm 0.0$ & $0.1 \pm 0.1$ & - & $2.6 \pm 0.1$ & $0.2 \pm 0.0$ & - \\
\hline $160-200+$ & $910 \pm 0.8$ & $1.320 \pm 0,0$ & $2.5 \pm 0.0$ & - & - & $2.2 \pm 0.1$ & $0.3 \pm 0.1$ & - \\
\hline
\end{tabular}

The data represent the mean values $(n=5) \pm$ standard deviation. $\rho$ : soil bulk density; FLF: free light fraction; IALF: intra-aggregate light fraction; F-clay: clay fraction; F-silt: silt fraction; F-sand: sand fraction. -: values lower than 0.1.

conservation in the terrestrial ecosystems. The fast incorporation of plant litter and the plant diversity which makes up AFS and SS may have an influence on soil $\mathrm{C}$ maintenance.
The total $\mathrm{C}$ stocks up to a $2 \mathrm{~m}$ depth show the potential of well-managed tropical soils in retaining $\mathrm{C}$ associated with the capacity of environments in maintaining $\mathrm{C}$ in the surface soil layers. The 
Table 3. Total carbon stocks in the soil fractions up to a $200 \mathrm{~cm}$ depth in primary forest (PF), pasture (P), secondary succession (SS), and agroforestry system (AFS) in Central Amazonia

\begin{tabular}{|c|c|c|c|c|c|c|}
\hline Ecosystem & FLF & IALF & F-Silt & F-Clay & F-Sand & Total \\
\hline & \multicolumn{6}{|c|}{$\mathrm{Mg} \mathrm{ha}^{-1}$ of $\mathrm{C}$} \\
\hline $\mathrm{PF}$ & $23.1 \pm 3.3$ & $0.4 \pm 0$ & $14.0 \pm 0.5$ & $53.4 \pm 3.5$ & $7.5 \pm 0.5$ & $98.4 \pm 7.8$ \\
\hline $\mathrm{P}$ & $7.9 \pm 1.0$ & $0.3 \pm 0$ & $10.0 \pm 0.6$ & $41.0 \pm 1.0$ & $4.8 \pm 0.5$ & $64.0 \pm 3.1$ \\
\hline SS & $23.2 \pm 3.8$ & $0.8 \pm 0$ & $22.2 \pm 0.6$ & $40.4 \pm 1.6$ & $6.3 \pm 1.0$ & $92.9 \pm 7.0$ \\
\hline AFS & $26.4 \pm 6.2$ & $2.0 \pm 0.5$ & $23.0 \pm 0.3$ & $44.4 \pm 2.0$ & $5.5 \pm 0.3$ & $101.3 \pm 9.3$ \\
\hline
\end{tabular}

FLF: free light fraction; IALF: intra-aggregate fraction; F-clay: clay fraction; F-silt: silt fraction; F-sand: sand fraction. The dispersion values represent mean values of five samples $(n=5) \pm$ standard deviation of $C$ stocks in the different fractions obtained in each ecosystem.

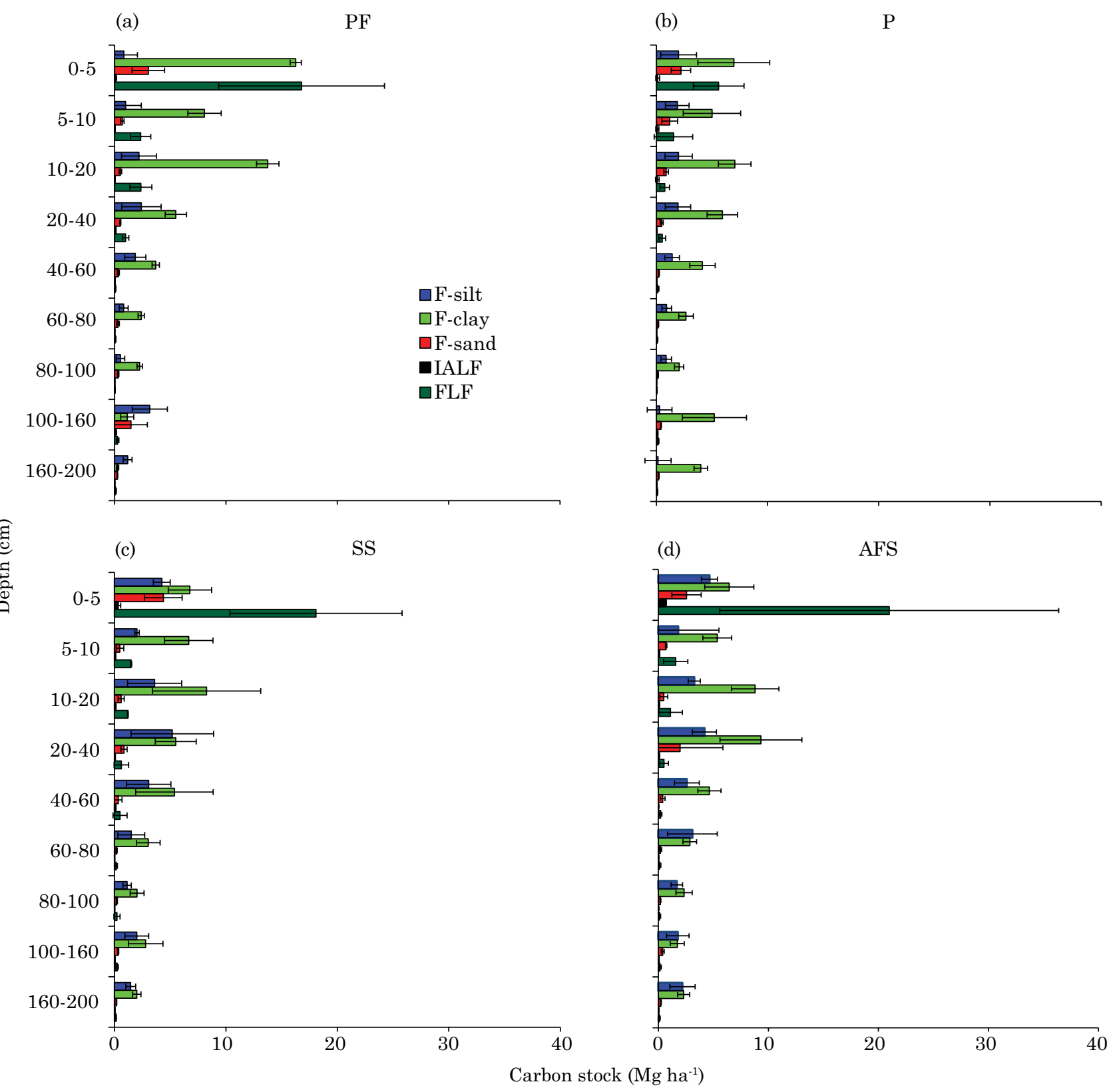

Figure 1. Carbon stocks in light and heavy fractions at different depths in primary forest (PF) (a), pasture (P) (b), secondary succession (SS) (c), and agroforest system (AFS) (d) in Central Amazonia. The bars represent the stocks of carbon at each depth in the different fractions, by depth, with their respective standard deviation. F-clay: clay fraction; F-silt: silt fraction; F-sand: sand fraction; FLF: free light fraction; IALF: intra-aggregate light fraction. 
increases in $\mathrm{C}$ stocks on the surface are associated with a larger volume of organic residues from vegetation which returned to the soil, and also to a larger SOC stock. Furthermore, the FLF, also known as the labile fraction, can be renewed and maintained in a short period of time, contributing to the high stock in this fraction, despite the low soil bulk density values in these layers. The roots found in SS and AFS may be responsible for the $\mathrm{C}$ contents and stocks found on the surface of the labile soil fraction (Marques et al., 2012) since the smaller diameters of the fine roots contribute to the quick uptake and decomposition of the nutrients when compared to more lignified roots, as found in the forest (Luizão, 2007).

Most of the $\mathrm{C}$ that is stored in the soil matrix is independent of the source material (Paul et al., 2008) and is directly related to the source of $\mathrm{C}$ from vegetation growing on the ground and management practices made in the soil. The stocks of total $\mathrm{C}$ and the $\mathrm{C}$ contained in the fractions show that in the Amazon, the introduction of enriched or secondary succession areas, as well as AFS are the most feasible alternatives for recovering soil organic $\mathrm{C}$ in degraded and/or abandoned areas. The litter produced by different systems is one of the factors that promotes the renewal of $\mathrm{C}$ stocks in the soil. For this contribution to be more effective, new litter produced by AFS should be diversified and the nutritional quality sufficient to fulfill its key roles in the ecosystem: keeping the soil covered and protected from the direct impacts of rain and sun, thus maintaining a better moisture level in the soil, and the soil biota in turn providing $\mathrm{C}$ and nutrients released by decomposition and contributing to the formation of new SOM (Frouz et al., 2007). This is achieved more quickly when the AFS are more diverse and more dense, which would be reflected sooner in higher production (due to a more closed canopy) and more diverse litter (due to the larger number of species, producing materials of different chemical qualities) (Luizão, 2007). Other previous experiments show that land agroecosystems can be a critical point in sequestering atmospheric $\mathrm{CO}_{2}$ and important for future mitigation of atmospheric $\mathrm{CO}_{2}$ (Cheng et al., 2007).

The root system is responsible for physical protection of $\mathrm{C}$ in the soil surface and the $\mathrm{C}$ stored in the aggregates (IALF), and represents a small part of the biologically active C. Von Lützow et al. (2006) emphasize that in tropical forest areas, biological activity leads to an increase in the soil labile fraction, depending on the decomposition ratio, which is controlled by the primary recalcitrance of litter. Studies show that aggregates contain the labile $\mathrm{C}$ which is physically protected from microbial decomposition, and they have the capacity for storing a large amount of $\mathrm{C}$ (Amelung and Zech, 1999). The differences obtained in regard to the stability and composition of the $\mathrm{C}$ that makes up the intra-aggregate light fraction are supposedly the result of the recalcitrance and of the protective mechanism of soil aggregation (John et al., 2005; Yamashita et al., 2006).

A large area of the central Amazon is composed of soils that are very clayey, porous, with many micropores, with high soil water retention and hydraulic conductivity prevailing (Marques et al., 2004), and C cycling becomes more dependent on the practices used to maintain soil C. The higher clay and silt percentage obtained in the soils show that the protection exerted on soil $\mathrm{C}$ is high at depths. The greater the specific surface of the particle, the greater the ability of that particle to interact with SOM. In the clayey loam soils that predominate in the Amazon, the SOC is dependent, in depth, of the finer fraction (F-clay), whereas in sandy soils, the highest proportion of $\mathrm{C}$ would be in the sand fraction (Roscoe and Machado, 2002).

\section{Importance of tropical soil management on the carbon contained in the physical fractions up to a 2-m depth}

The forest soil showed the highest $\mathrm{C}$ percentages in the FLF, F-clay and F-sand up to a $200 \mathrm{~cm}$ depth (Table 2), showing the action of the roots and of the soil biota at depths in $\mathrm{C}$ translocation through the fine and coarse litter. The results showed that it is possible to recover abandoned and/or degraded areas, resulting from forest clearing in Amazonia, through the introduction of AFS or SS. Agroforestry systems are the most adequate agricultural procedures for tropical regions, with maintenance of 70 to $80 \%$ of the plant cover as permanent trees, mimicking a forest (Mutuo et al., 2005).

The potential of SS and AFS in maintaining or increasing the gain in soil $\mathrm{C}$ has also been observed in other studies (Froufe et al., 2011; Marques et al., 2012). Mutuo et al. (2005) describe that agrosilvicultural systems such as agroforestry accumulated approximately $60 \%$ of the initial inventories in approximately 30 years, while pasture after cutting and burning this environment lead to a gradual decline in terms of $\mathrm{C}$ systems. Although pastures in the humid tropics may be controlled to maintain high stocks of soil C, their effectiveness in soil $\mathrm{C}$ sequestration is gradually reduced due to declines in pasture production because of poor management.

Inadequate management of these soils causes a loss in the enrichment of $\mathrm{C}$ macroaggregates and a gain in microaggregates. When soils are subjected to intensive cultivation, physical changes such as compression may limit the growth and activity of microorganisms by changing the atmosphere of the soil, thus reducing the decomposition rate of the SOM. The cultivation of virgin soil leads to great losses of SOC (Solomon et al., 2002). 
The 0-5, 5-10, 10-20, and 20-40 cm layers are enriched with $\mathrm{C}$ in the FLF, making them an important fraction in the quality evaluation of the short-term management system (Conceição et al., 2005). Primary forest areas allow for SOC conservation in the ecosystem in different soil fractions. McGrath et al. (2001) showed that there is no significant difference in organic $\mathrm{C}$ concentration between a primary forest area and six-year agroforestry systems. In the same way, Tapia-Coral et al. (2005) found higher $\mathrm{C}$ concentrations in a managed forest as compared to a primary forest. This is directly related to more intense aggregation of these soils on the surface, while the higher contents of the FLF (labile) are directly related to the action of roots and leaves deposited on the surface, promoting mechanical protection of organic matter. Up to a $1 \mathrm{~m}$ depth, C in the heavy fractions (F-sand, F-clay, and F-silt) is not directly affected by soil use and management. In the case of changes in the environments under study, the decrease in $\mathrm{C}$ in the heavy fractions may occur slowly, differing from the FLF and the IALF, where this loss can occur quickly.

When tropical forests are cultivated, the $\mathrm{C}$ loss at the $1 \mathrm{~m}$ depth is around 15 to $40 \%$ over a period of two to three years (Ingram and Fernandes, 2001), reducing soil fertility and the harvest yield. When native ecosystems are disturbed by human activities, dynamic balance is broken, and usually inputs of $\mathrm{C}$ are less than outputs, which leads to a reduction in the quantity of SOM and modification of its quality (Cerri et al., 2008). Other factors that have been classified as immediate causes of a decline in SOC include residue removal, soil erosion, intensive tillage and bare fallowing (Lal and Kimble, 2000). Awiti et al. (2008) show that changes in the forest for other uses reduce soil $\mathrm{C}$ and $\mathrm{N}$ due to changes in biomass and litter input, mainly on the surface (Martens et al., 2003). Other studies confirm the results found here, emphasizing that AFS has the potential for restoring degraded land, maintaining soil fertility and, more recently, sequestering $\mathrm{C}$, mitigating $\mathrm{C}$ emissions to the atmosphere (Oelbermann et al., 2004; Mutuo et al., 2005). Carbon stocks can be increased to values above 60 $\mathrm{Mg} \mathrm{ha}^{-1}$, showing values higher than in pastures, depending on the age of the rotation system and on the land use system (Mutuo et al., 2005).

Freixo et al. (2002) report that $\mathrm{C}$ losses in cultivated areas at a depth of $5 \mathrm{~cm}$ can reach $47 \%$ in conventional crop areas and from 23 to $29 \%$ in crop rotation areas. Comparing the FLF in the $\mathrm{PF}, \mathrm{SS}$, and AFS on the surface layer, it may be observed that SS and AFS are viable alternatives for recovery of degraded and intensively cropped soil in the Amazon.

The highest $\mathrm{C}$ losses among the environments occurred in the forest to pasture transition, with a release of $22.43 \%$ of the $\mathrm{C}$ contained in the labile fraction (Marin-Spiotta et al., 2009; Paul et al., 2008). Carbon contents in all fractions in SS and AFS were higher at all depths when compared to the pasture environment. The recovery pasture areas or enhancement of management areas in the Amazon are effective ways to maintain soil C.

Sanchez et al. (2003) emphasize that the conversion of tropical forests to different types of agroforests results in a smaller C loss compared to conversion to pasture areas. Increased concern about the environmental impacts of conventional crop production has stimulated interest in alternative systems. Agroforestry system and SS are systems able to promote and maintain soil biological processes, increasing SOC and improving the physical and chemical properties of the soil. All activities aimed at the increase of SOM help in creating a new equilibrium in the agro-ecosystem. Mutuo et al. (2005) describe that AFS multistrata have the ability to recover $\mathrm{C}$ stocks in terrestrial ecosystem in less quantities, but with similar rates to SS. The management of the AFS allows the development of a growing process of $\mathrm{C}$ storage, by increasing efficiency of photosynthesis, increasing primary productivity and significantly reducing emissions of $\mathrm{CO}_{2}$ and other greenhouse gases $\left(\mathrm{N}_{2} \mathrm{O}\right.$ and $\mathrm{CH}_{4}$ ) compared to other cultivation and forest ecosystems systems. The importance of organic matter input from trees help maintain and increase SOM and this has been shown by many studies in tropical and temperate agroforest systems (Oelbermann et al., 2004).

The conversion of natural ecosystems, such as the Amazon, into agricultural systems may represent emissions from 1 to $9 \mathrm{Gt} \mathrm{ha}^{-1} \mathrm{yr}^{-1}$ of $\mathrm{C}$ (Mutuo et al., 2005). In this case, the use of system studies and soil management under SS and AFS are potential alternatives to maintain and/or increase the $\mathrm{C}$ stored in the soil; however, research in these environments is still necessary to elucidate their interactions in the soil-plant-atmosphere system.

\section{CONCLUSIONS}

Soil carbon present on the surface is associated with the labile fractions, while soil carbon at greater depths is retained in the heavy fine fractions (clay and silt fractions).

The establishment of SS and AFS in areas abandoned after pasture use resulted in less loss of carbon, recovering the labile soil fraction.

Carbon distribution at greater depths is heterogeneous in soil fractions, showing the effects of soil use and management and the FLF and F-clay may be affected in the short- and long-term, respectively. 


\section{ACKNOWLEDGMENTS}

The authors would like to thank the LBA, PELD, PPG7 Project, and the CNPq for financial support.

\section{REFERENCES}

Amelung W, Zech W. Minimisation of organic matter disruption during particle-size fractionation of grassland epipedons. Geoderma. 1999;92:73-85.

Araújo EA, Ker JC, Mendonça ES, Silva IR, Oliveira EK. Impacto da conversão floresta - pastagem nos estoques e na dinâmica do carbono e substâncias húmicas do solo no bioma Amazônico. Acta Amaz. 2011;41:103-14.

Awiti AO, Walsh MG, Kinyamario J. Dynamics of topsoil carbon and nitrogen along a tropical forest-cropland chronosequence: Evidence from stable isotope analysis and spectroscopy. Agric Ecosyst Environ. 2008;127:265-72.

Bayer C, Martin-Neto L, Mielniczuk J, Dieckow J, Amado TJC. $\mathrm{C}$ and $\mathrm{N}$ stocks and the role of molecular recalcitrance and organomineral interaction in stabilizing soil organic matter in a subtropical Acrisol managed under no-tillage. Geoderma. 2006;133:258-68.

Campos DV. Uso da técnica de $13 \mathrm{C}$ e fracionamento físico da matéria orgânica em solos sob cobertura de pastagens e cana-de-açúcar na região da Mata Atlântica [tese]. Seropédica: Universidade Federal Rural do Rio de Janeiro; 2003.

Cardoso EL, Silva MLN, Silva CA, Curi N, Freitas DAF. Estoques de carbono e nitrogênio em solo sob florestas nativas e pastagens no bioma Pantanal. Pesq Agropec Bras. 2010;45:1028-35.

Carvalho JLN, Cerri CEP, Feigl BJ, Píccolo MC, Godinho VP, Cerri CC. Carbon sequestration in agricultural soils in the Cerrado region of the Brazilian Amazon. Soil Till Res. 2009; 103:342-49.

Cerri CEP, Feigl B, Cerri CC. Dinâmica da matéria orgânica do solo na Amazônia. In: Santos GA, Silva LS, Canellas LP, Camargo FO, editores. Fundamentos da matéria orgânica do solo: Ecossistemas tropicais e subtropicais. $2^{\text {a }}$ ed. Porto Alegre: Metrópole; 2008. p.325-358.

Cheng L, Leavitt SW, Kimball BA, Pinter Jr PJ, Ottman MJ, Matthias A, Wall GW, Brooks T, Williams DG, Thompson TL. Dynamics of labile and recalcitrant soil carbon pools in a sorghum free-air $\mathrm{CO}_{2}$ enrichment (FACE) agroecosystem. Soil Biol Biochem. 2007;39:2250-63.

Conceição PC, Amado TJC, Mielniczuk J, Spagnollo E. Qualidade do solo em sistemas de manejo avaliada pela dinâmica da matéria orgânica e atributos relacionados. $\mathrm{R}$ Bras Ci Solo. 2005;29:777-88.

Costa OV, Cantarutti RB, Fontes LEF, Costa LM, Nacif PGS, Farias JC. Estoque de carbono do solo sob pastagem em área de Tabuleiro Costeiro no sul da Bahia. R Bras Ci Solo. 2009;33:1137-45.

De Bona FD. Dinâmica da matéria orgânica do solo em sistemas irrigados por aspersão sob plantio direto e preparo convencional [tese]. Porto Alegre: Universidade Federal do Rio Grande do Sul; 2005.
Desjardins T, Barros E, Sarrazin M, Girardin C, Mariotti A. Effects of forest conversion to pasture on soil carbon content and dynamics in Brazilian Amazonia. Agric Ecosyst Environ. 2004;103:365-73.

Empresa Brasileira de Pesquisa Agropecuária - Embrapa. Manual de métodos de análise de solo. 2a ed. Rio de Janeiro: Centro Nacional de Pesquisa de Solos; 1997.

Empresa Brasileira de Pesquisa Agropecuária - Embrapa. Sistema brasileiro de ciência do solo. $2^{\text {a }}$ ed. Rio de Janeiro: Empresa Brasileira de Pesquisa Agropecuária; 2006.

Feldpausch TR, Rondon MA, Fernandes ECM, Riha SJ, Wandelli E. Carbon and nutrient accumulation in secondary forests regenerating on pastures in Central Amazonia. Ecol Appl. 2004;14:164-76.

Frouz J, Elhottová D, Pizl V, Tajousky K, Sourková M, Picek T, Maly, S. The effect of litter quality and soil faunal composition on organic matter dynamics in post-mining soil: a laboratory study. Appl Soil Ecol. 2007;37:72-80.

Freixo AA, Machado PLOA, Guimarães CM, Silva CA, Fadigas FS. Estoques de carbono e nitrogênio e distribuição de frações orgânicas de Latossolo do Cerrado sob diferentes sistemas de cultivo. R Bras Ci Solo. 2002;26:425-34.

Froufe LCM, Rachwal MFG, Seoane CES. Potencial de sistemas agroflorestais multiestrata para sequestro de carbono em áreas de ocorrência de Floresta Atlântica. Pesq Flor Bras. 2011;31:143-54.

Galvinelli E, Feller C, Larré-Larrouy MC, Bacye B, Djegui N, Nzila JD. A routine method to study soil organic matter by particle-size fractionation: Examples for tropical soils. Commun Soil Sci Plant Anal. 1995;26:1749-60.

Huang Z, Xu Z, Chen C. Effect of mulching on labile soil organic matter pools, microbial community functional diversity and nitrogen transformations in two hardwood plantations of subtropical Australia. Appl Soil Ecol. 2008;40:229-39.

Ingram JSI, Fernandes ECM. Managing carbon sequestration in soils: Concepts and terminology. Agric Ecosyst Environ. 2001;87:111-7.

International Union of Soil Sciences/Working Group - IUSS/WRB. World reference base for soil resources. Rome: Food and Agriculture Organization of the United Nations; 2006.

John B, Yamashita T, Ludwing B, Fless J. Storage of organic carbon in aggregate and density fractions of silty soils under different types of land use. Geoderma. 2005;128:63-79.

Lal R, Kmble JM. Tropical ecosystems and the global carbon cycle. In: Lal R, Kimble JM, Stewart BA, editors. Global Climate Change and Tropical Ecosystems. Boca Raton: Chemical Rubber Company-Lewis Publishers; 2000. p.3-32.

Luizão FJ. Ciclos de nutrientes na Amazônia: Respostas às mudanças ambientais e climáticas. Ci Cult. 2007;59:20-32.

Marchão RL, Becquer T, Brunet D, Balbino LC, Vilela L, Brossard M. Carbon and nitrogen stocks in a Brazilian clayey Oxisol: 13 years effects of integrated crop-livestock management systems. Soil Till Res. 2009;103:442-50.

Maia SMF, Ogle SM, Cerri CEP, Cerri CC. Effect of grassland management on soil carbon sequestration in Rondônia and Mato Grosso States, Brazil. Geoderma. 2009;149:84-91.

Marques JD, Libardi PL, Teixeira WG, Reis AM. Estudo de parâmetros físicos, químicos e hídricos de um Latossolo Amarelo, na região Amazônica. Acta Amaz. 2004;34:145-54. 
Marques JD, Luizão FJ, Teixeira WG, Ferreira SJF. Variações do carbono orgânico dissolvido e de atributos físicos do solo sob diferentes sistemas de uso da terra na Amazônia Central. R Bras Ci Solo. 2012;36:611-22.

Marin-Spiota E, Whendee LS, Christopher W, Swanston W, Ostertag R. Soil organic matter dynamics during 80 years of reforestation of tropical pastures. Global Change Biol. 2009;15:1584-97.

Martens DA, Reedy TE, Lewis DT. Soil organic carbon content and composition of 13 years crop, pasture and forest land-use managements. Global Change Biol. 2003;10:65-78.

McGrath DA, Smith CK, Gholz H, Oliveira F. Effects of land-use change on soil nutrient dynamics in Amazônia. Ecosystems. 2001;4:625-45.

Mutuo PK, Cadisch G, Albrecht A, Palm CA, Verchot L. Potential of agroforestry for carbon sequestration and mitigation of greenhouse gas emissions from soils in the tropics. Nutr Cycl Agroecosyst. 2005;71:43-54.

Oelbermann M, Voroney RP, Gordon AM. Carbon sequestration in tropical and temperate agroforestry systems: A review with examples from Costa Rica and Southern Canada. Agric Ecosyst. Environ. 2004;104:359-77.

Passos RR, Ruiz HA, Cantarutti RB, Mendonça ES. Carbono orgânico e nitrogênio em agregados de um Latossolo Vermelho distrófico sob duas coberturas vegetais. R Bras Ci Solo. 2007;31:1109-18.

Paul S, Veldkamp E, Flessa H. Soil organic carbon in density fractions of tropical soils under forest-pasture-secondary forest land use changes. Eur J Soil Sci. 2008;59:359-71.

Pillon CN. Alterações no conteúdo e qualidade da matéria orgânica do solo induzidas por sistemas de cultura em plantio direto [tese]. Porto Alegre: Universidade Federal do Rio Grande do Sul; 2000.

Pinheiro EFM, Pereira MG, Anjos LHC, Machado PLOA. Fracionamento densimétrico da matéria orgânica do solo sob diferentes sistemas de manejo e cobertura vegetal em Paty do Alferes. R Bras Ci Solo. 2004;28:731-37.

Rangel OJ, Silva CA. Estoques de carbono e nitrogênio e frações orgânicas de Latossolo submetido a diferentes sistemas de uso e manejo. R Bras Ci Solo. 2007;31:1609-23.

Roscoe R, Buurman P. Disruption of soil aggregates by varied amount of ultrasonic energy in fractionation of clay Latosol. Eur J Soil Sci. 2000;51:445-54.

Roscoe R, Machado PLOA. Fracionamento físico do solo em estudos da matéria orgânica. Dourados: Empresa Brasileira de Pesquisa Agropecuária; 2002.
Sanchez PA, Palm CA, Buol SW. Fertility capability soil classification: A tool to help assess soil quality in the tropics. Geoderma. 2003;114:157-85.

Silva JE, Resck DVS, Corazza EJ, Vivaldi L. Carbon storage under cultivated pastures in a clayey Oxisol in the Cerrado Region, Brazil. Agric Ecosyst Environ. 2004;103:357-63.

Silva Junior ML, Desjardins T, Sarrazin M, Melo VS, Santos ER, Carvalho JR. Carbon content in Amazonian Oxisols after Forest conversion to pasture. R Bras Ci Solo. 2009;33:1603-11.

Sisti CPJ, Santos HP, Kohhan R, Alves BJR, Urquiaga S, Bodey RM. Change in carbon and nitrogen stocks in soil under 13 years of conventional or zero tillage in southern Brazil. Soil Till Res. 2004;76:39-58.

Soares R. Agregação e distribuição da matéria orgânica em solos de Terra Preta de Índio da Amazônia Central [doutorado]. Rio de Janeiro: Universidade Federal Fluminense; 2007.

Sohi S, Mahieu N, Arah JRM, Powlson DSP, Madari B, Gaunt JL. Procedure for isolating soil organic matter fractions suitable for modeling. Soil Sci Soc Am J. 2001;65:1121-8.

Soil Survey Staff. Keys to soil taxonomy. Washington: Natural Resources Conservation Service; 1998.

Solomon D, Fritzsche F, Tekaling M, Lehmann J, Zech W. Soil organic matter composition in the subhumid Ethiopian Highlands as influenced by deforestation and agricultural management. Soil Sci Soc Am J. 2002;66:68-82.

Souza ED, Costa SEVGA, Anghinoni I, Carvalho PCF, Andrigueti M, Cao E. Estoque de carbono orgânico e de nitrogênio no solo em sistemas de integração lavoura pecuária em plantio direto, submetido à intensidade de pastejo. $\mathrm{R}$ Bras Ci Solo. 2009;33:1829-36, 2009.

Stürmer SLK, Rossato OB, Copetti ACC, Santos DR, Calegari A, Brum B. Variações nos teores de carbono orgânico em função do desmatamento e revegetação natural do solo. Ci Flor. 2011;21:241-50.

Tapia-Coral SC, Luizão FJ, Wandelli EL, Fernandes ECM. Carbon and nutrient stocks in the litter layer of agroforestry systems in central Amazonia, Brazil. Agrofor Syst. 2005;65:33-42.

Yamashita T, Flessa H, John B, Helfrich M, Ludwing B. Organic matter in density fractions of water-stable aggregates in silty soils: Effect of land use. Soil Biol Biochem. 2006;38:3222-34.

Von Lützow M, Kogel-Knabner I, Ekschmitt K, Matzner E, Guggenberger G, Marschner, B. Stabilization of organic matter in temperate soils: Mechanisms and their relevance under different soil conditions. Eur J Soil Sci. 2006;57:426-45. 